\title{
Nutritive Value of Diets Containing Digeston-1 as a Feed Additive for Nile Tilapia (Oreochromis niloticus) Fingerlings
}

Malik M Khalafalla*

Animal Production Department, Faculty of Agriculture, Kafrelsheikh University, Kafr Elsheikh 33516, Egypt

\begin{abstract}
Digeston-1 (fermented soybean meal) is produced by controlled lactic acid fermentation with natural lactic acid bacteria. In the present study, a total of 150 fish with average initial body weight $10.11 \mathrm{~g}$ were randomly stocked into 15 aquaria to study the effect of Digeston-1 on performance and growth parameters of Nile tilapia (Oreochromis niloticus) fingerlings. Results revealed that the group fed diet contain Digeston-1 recorded the highest $(P<0.05)$ growth parameters in terms of final body weight gain, average daily gain and specific growth rate compared with those fed the control diet. The Nile tilapia in the trial groups consumed less feed, which led to a considerable reduction of the feed costs. The results also showed that the FCR, PER and PPV\% were high significantly $(P<0.05)$ for fish fed diet containing Digeston-1 compared to fed control diet. Body composition; DM, CP, EE, Ash and energy content of Nile tilapia during the experiment showed no changes in whole body composition among all experimental diets. Results of Hematological parameters (WBCs, RBCs, Hb, PCV and Differential leucocytes count) of fish fed diets containing various levels of Digeston-1 indicated that there were no significant $(P>0.05)$ differences among the tested dietary treatments. The treated diets had slightly higher white blood cells count, red blood cells count, hemoglobin and PCV than control diet. On contrast, total protein was increased $(P>0.05)$ by Digeston-1 supplementation specifically, by $0.50 \%$ and $0.70 \%$ level. Moreover, Digeston-1 supplementation had no significant effect $(P>0.05)$ on Aspartate aminotransferase (AST) and alanine aminotransferase (ALT) concentrations compared with unsupplemented group. It is concluded that the addition of Digeston- 1 diets at $0.5 \%$ level improve and enhance the growth performance of Nile tilapia, Oreochromis niloticus, fingerlings.
\end{abstract}

Keywords: Digeston-1; Nile tilapia; Oreochromis niloticus; Growth parameters

\section{Introduction}

Soybean meal (SBM) is commonly used as an effective plantderived protein in animal feed industry. DIGESTON-1 is a concentrate of live lactic acid bacteria carried on a base of soya bean meal. However, variety of antinutritional factors (ANFs), such as trypsin inhibitor and lectins and soya globulins contained in soybeans are limiting the wide application of soybean meal in animal especially young animal feed $[1,2]$. In Far East Asia, fermentation processes have been used to prepare traditional soybean food commonly known as "Dou-BianJiang" in China, "Miso" in Japan, and "DuenJang" in Korea [3]. These fermented soy food are highly digestible and nutritious, contributing important nutrients including calcium and Vitamins A and B, as well as functional properties such as laxative effects, and anti-cancer properties [4].

Currently, considerable attention is being given to the use of probiotics in animal feeding programs. Traditional probiotics are lactic acid bacteria, such as Lactobacillus casei, L.acidophilus and Streptococci. Probiotics regulate the microbial environment of the intestine, decrease disturbances, inhibit pathogenic intestinal micro-organisms and improve feed conversion efficiency [5]. As a probiotic agent, it may act through improvement of the balance of the intestinal microflora. It improves health performance and increases growth rates [6]. The most positive effect is expected especially in suboptimal hygienic conditions in indoor animals. Lactobacilli are widely distributed on the surface of plants, in digestive tract of animals and in the environment.

Wu and Jing [7] suggested that, fermentation could improve protein digestibility, essential amino acid index and protein efficiency ratio of soybean meal. Fermented soybean meal (FSBM) is manufactured through fermentation of dehulled soybean meal by high active yeast, lactic acid bacteria and Bacillus, and drying. It is assumed that the
FSBM in his study was a purified product and fermented so that the anti-nutritional factors were partly destroyed. You have to be sure whether it is purified product or not. Fermentation using Lactobacillus $s p$. has been used to reduce the levels of non-starch carbohydrates in wheat and barley whole meals $[8,9]$.

According to our knowledge, the information regarding effects of Digeston-1 on growth performance in fish is limited. Therefore, the current study was conducted to evaluate growth performance and plasma biochemical parameters in Nile tilapia (Oreochromis niloticus) fingerlings fed a FSBM diet.

\section{Materials and Methods}

This work was carried out during summer season, 2012 at the Wet Fish Lab., Department of Animal Production, Faculty of Agriculture, Kafrelsheikh University, Egypt.

\section{Digeston-1}

Fermentation products such as Digeston-1 are made by specific lactic acid fermentation of heat treated soybean meal and malt, using a multiple mixture of lactobacilli and pediococcus, selected from their natural habit. It contains a) viable lactic acid bacteria ( $L$. plantarum, $L$.

*Corresponding author: Malik M Khalafalla, Animal Production Department Faculty of Agriculture, Kafrelsheikh University, Kafr Elsheikh 33516, Egypt, E-mail: malikkhalafalla@yahoo.com

Received June 24, 2013; Accepted July 25, 2013; Published July 29, 2013

Citation: Khalafalla MM (2013) Nutritive Value of Diets Containing Digeston-1 as a Feed Additive for Nile Tilapia (Oreochromis niloticus) Fingerlings. J Aquac Res Development 4: 192 doi:10.4172/2155-9546.1000192

Copyright: (c) 2013 Mancuso M, et al. This is an open-access article distributed under the terms of the Creative Commons Attribution License, which permits unrestricted use, distribution, and reproduction in any medium, provided the original author and source are credited. 
Citation: Khalafalla MM (2013) Nutritive Value of Diets Containing Digeston-1 as a Feed Additive for Nile Tilapia (Oreochromis niloticus) Fingerlings. J Aquac Res Development 4: 192 doi:10.4172/2155-9546.1000192

Page 2 of 5

brevis, $L$. reuteri, $L$.casei and pediococcus acidilactici). b) Lactic acid fermentation metabolites and enzymes (organic acids, glucosidase and peptidase enz.). c) Free (soluble) amino acids and short-chain peptides.

(From Produktionsgemeinschaft F. u. H. EGGER GmbH, AT 4011 A-8413 Mitterlabill 19, Austria) (Table 1).

\section{Experimental fish}

Nile tilapia (Oreochromis niloticus) fingerlings were obtained from a private fish farm at Tolompate 7, Kafr El-Sheikh governorate, Egypt. Fingerlings were placed in a fiberglass tank and randomly distributed into glass aquaria to be adapted to the experimental condition until starting the experiment. All fish were fed the control diet during the first 7 days after stocking to adapt them to feeding and handling practices. After that, the fish were fed the experimental diets.

\section{Experimental design of rearing fish}

Fish $(\mathrm{n}=150 ; 10.11 \pm 0.07 \mathrm{~g})$ were randomly divided into fifteen aquaria $(70 \mathrm{~L}$ each) in triplicates $(10 \mathrm{fish}$ per replicate). One third of water aquaria were replaced daily and totally once a week after removing wastes. Fresh tap water was stored in fiberglass tanks for $24 \mathrm{~h}$ under aeration for chlorination. Fifteen air stones were used for aerating the aquaria water. All aquaria were maintained under a constant photoperiod ( $12 \mathrm{~h}$ dark/light) provided by white fluorescent lamps. Fish feces and feed residue were removed daily by siphoning.

\section{Experimental diets and feeding regime}

The fish were adapted to a basal commercial diet [control diet (T1)] containing $30.11 \%$ crude protein and were consisted of herring fish meal, soybean meal, yellow corn, rice bran and wheat bran for two weeks. Four experimental commercial diets were formulated to contain 0.1, 0.3, 0.5 and 0.7\% Digeston-1 (Table 2).

A basal diet was formulated using the commercial ingredients. The dry ingredients were finely ground and mixed by a dough mixer for 20 minutes for homogeneity. Oil was gradually added while mixing. After homogenous mixture, forty $\mathrm{ml}$ water per hundred gm. diet was slowly added to the mixture according to Shimeino et al. [10]. The diets were cooked on the water evaporator for 20 minutes. The diets were pelleted $(3 \mathrm{~mm})$ through fodder machine and the manufacture pellets were dried using oven at $70^{\circ} \mathrm{C}$ for 48 hours. The diets were collected, tagged and stored in a refrigerator at $4^{\circ} \mathrm{C}$.

Fish in all treatment were daily fed the experimental diets at a level of 5, 4 and $3 \%$ of the body weight daily for the first, the second and the third four weeks, respectively. Feed amount was given three times daily $(900,1200$ and 1500) in equal portions, six days a week for 12 weeks. Fish were weighed biweekly and feed amounts were adjusted on the basis of the new weight. Mortality was monitored daily and recorded.

\section{Analytical procedures}

Moisture, crude protein $(\% \mathrm{~N} \times 6.25)$, crude lipid, crude fiber and

\begin{tabular}{|l|c|}
\hline Proximate composition (\%) & DIGESTON-1 \\
\hline Crude protein & 48 \\
\hline Crude fiber & 5.4 \\
\hline Crude ash & 6.3 \\
\hline Crude oil and fat & 2.2 \\
\hline Sodium & 2 \\
\hline Lysine & 3 \\
\hline Methionine & 0.7 \\
\hline
\end{tabular}

Table 1: Proximate composition of Digeston-1 used in the experiment (\%).

\begin{tabular}{|l|c|}
\hline Items & Control diet (On DM basis, \%) \\
\hline Feed ingredients & 10 \\
\hline Herring fish meal, 72\% CP & 42 \\
\hline Soybean meal, 44\% CP & 24 \\
\hline Yellow corn & 10 \\
\hline Rice bran & 10 \\
\hline Wheat bran & 3.0 \\
\hline Sunflower oil & 0.5 \\
\hline Vitamins ${ }^{1}$ & 0.5 \\
\hline Minerals premix ${ }^{2}$ & 100 \\
\hline Total & \\
\hline Chemical composition $(\%)$ & 88.98 \\
\hline Dry matter & 30.11 \\
\hline Crude protein & 8.19 \\
\hline Ether extract & 7.50 \\
\hline Crude fiber & 7.71 \\
\hline Total ash & 46.49 \\
\hline Nitrogen free extract ${ }^{3}$ & \\
\hline Calculated energy value & 4437 \\
\hline GE (kcal/kg $)^{4}$ & 3328 \\
\hline DE (kcal/kg) & 90.47 \\
\hline P/E, mg/kcal ${ }^{6}$ & \\
\hline
\end{tabular}

${ }^{1}$ Mineral premix consisted of ( $\mathrm{mg} \mathrm{kg}^{-1}$ premix): $2600 \mathrm{mg} \mathrm{Mn}, 600 \mathrm{mg} \mathrm{Cu}, 6000 \mathrm{mg}$ $\mathrm{Fe}, 4600 \mathrm{mg} \mathrm{Zn}, 50 \mathrm{mg} \mathrm{Se}, 100 \mathrm{mg}$ lu, $50 \mathrm{mg} \mathrm{Co}, 100,000 \mathrm{mg}$ choline chloride, up to $1 \mathrm{~kg}$ carrier (Local market).

${ }^{2}$ Vitamin premix consisted of ( $\mathrm{mg} \mathrm{kg}^{-1}$ premix): 1,200, 000 IU Vitamin A, 400,000 IU Vitamin D3, 3000 IU Vitamin E, $1200 \mathrm{mg} \mathrm{K3,5400} \mathrm{mg} \mathrm{C,} 200 \mathrm{mg} \mathrm{2,} 200 \mathrm{mg}$ B1, $3360 \mathrm{mg} \mathrm{B} 2,7200 \mathrm{mg} \mathrm{B}, 9000 \mathrm{mg} \mathrm{B} 5,2400 \mathrm{mg} \mathrm{B} 6,600 \mathrm{mg} \mathrm{B}, 4 \mathrm{mg} \mathrm{B} 12$ (Local market).

${ }^{3}$ Nitrogen free extract concluded by difference

${ }^{4} \mathrm{GE}$ (Gross energy) was calculated according to NRC [12] by using factors of 5.65 9.45 and $4.22 \mathrm{~K}$ cal per gram of protein, lipid and carbohydrate, respectively .

${ }^{5} \mathrm{DE}$ (Digestible energy) was calculated by applying the coefficient of 0.75 to convert gross energy to digestible energy according to Hepher et al. [39].

${ }^{6} \mathrm{P} / \mathrm{E}$ (protein energy ratio)=crude protein $\times 1000 /$ digestible energy $/ 100 \mathrm{~g}$, according to Hepher et al. [39]

**Treatments: $T_{1}$ (control): without supplements, $T_{2}: 0.1 \%$ DIGESTON-1, $T_{3}: 0.3 \%$ DIGESTON-1, $\mathrm{T}_{4}: 0.5 \%$ DIGESTON-1 and $\mathrm{T}_{5}: 0.7 \%$ DIGESTON-1.

${ }^{* *}$ Values of diets content were within the range suggested for tilapia by Jauncey and Ross [40] and NRC [12]

Table 2: Composition and proximate analysis of the experimental diet.

ash contents of diet ingredients and a sample of fish at the beginning and end of the experiment were determined in triplicate according to A.O.A.C [11] methods as follows: moisture was determined by ovendrying at $105^{\circ} \mathrm{C}$ for $24 \mathrm{~h}$; lipid by extracting the residue with $40-60^{\circ} \mathrm{C}$ petroleum ether for $16 \mathrm{~h}$; fiber as loss on ignition of dried lipid-free residues after digestion with $1.25 \% \mathrm{H}_{2} \mathrm{SO}_{4}$ and $1.25 \% \mathrm{NaOH}$; ash by ignition at $550-600^{\circ} \mathrm{C}$ to constant weight; total nitrogen by microKjeldahl method. Gross energy (GE) contents of the experimental diets and fish samples were calculated using factors of 5.65, 9.45 and 4.22 $\mathrm{kcal} / \mathrm{g}$ of protein, lipid and carbohydrates, respectively [12].

\section{Measurements of water parameters}

Water samples were taken each two days for ammonia and $\mathrm{pH}$ analysis. Analytical methods were done according to the American Public Health Association [13]. The pH values were determined by a digital $\mathrm{pH}$-meter. Water temperature and oxygen level were measured daily at 8 o'clock by Oxygen meter model 9070 . In all treatments, water quality parameters for water temperature ranged between 27.00 to $27.80^{\circ} \mathrm{C}, \mathrm{pH}$ ranged from 7.22 to 7.54 ; dissolved oxygen ranged from 6.33 to $6.88 \mathrm{mg} / \mathrm{L}$ and water ammonia ranged from 0.06 to $0.10 \mathrm{mg} / \mathrm{L}$. All the water quality parameters were within the acceptable ranges for fish growth [14]. 
Citation: Khalafalla MM (2013) Nutritive Value of Diets Containing Digeston-1 as a Feed Additive for Nile Tilapia (Oreochromis niloticus) Fingerlings. J Aquac Res Development 4: 192 doi:10.4172/2155-9546.1000192

Page 3 of 5

\section{Measurements of growth and feed utilization parameters}

Body weight of fish in each aquarium was measured at start and every two weeks during the experimental period (12 weeks). Diet performance was evaluated as follows:

-Average weight gain, AWG (g/fish) $=\mathrm{W}_{\mathrm{t}}-\mathrm{W}_{0}$.

-Average daily weight gain, ADG (g/fish/day) $=\mathrm{W}_{\mathrm{t}}-\mathrm{W}_{0} / \mathrm{t}$.

-Specific growth rate $\%$ day, SGR $(\% /$ day $)=100 \times\left(\operatorname{In~}_{\mathrm{t}}-\mathrm{In} \mathrm{W}_{0}\right) / \mathrm{t}$

${ }^{*}$ Where $\mathrm{W}_{\mathrm{t}}$ is weight of fish at time $\mathrm{t}, \mathrm{W}_{0}$ is weight of fish at time 0 , and $t$ is the experimental period in days.

-Feed conversion ratio, FCR=dry feed fed/wet weight gain.

-Protein efficiency ratio, PER= wet weight gain/Protein fed.

-Protein productive value, PPV (\%)=100 $\times$ (protein gain/protein fed $)$.

-Survival rate, $S R=100$ (Total No. of fish at the end of the experimental/Total No. of fish at the start of the experiment].

\section{Blood parameters determination}

At the end of the experiment, fish in each aquaria were weighed and three blood samples were taken randomly from the caudal vein for blood analysis and differential leukocyte count, Anti coagulated blood samples were prepared immediately for counting red and white blood cells etc.

Red blood cells count $\left(\mathrm{RBCs} \times 10^{6} \mid \mathrm{mm}^{3}\right)$ and white blood cells count $\left(\right.$ WBCs $\left.\times 10^{3} \mid \mathrm{mm}^{3}\right)$ : were measured on an A bright-line Haemocytometer model (Neubauer improved, Precicolor HBG, Germany) by using a commercial kits (Ranox company, Germany) according to the method described by [15]. Hemoglobin concentration ( $\mathrm{Hb} \mathrm{gm} / \mathrm{dl}$ ): was determined according to the method of Zinkl [16]. Packed cell volume (PCV \%) was estimated by the microhaematocrite method as described by Dacie and Lewis [17]. Differential leukocyte count, the relative and absolute count was estimated according to Vankamlen [18].

\begin{tabular}{|c|c|c|c|c|c|c|}
\hline \multirow[t]{2}{*}{ Items } & \multicolumn{5}{|c|}{ Treatments No (On DM basis, \%) } & \multirow[t]{2}{*}{$\mathrm{SE}^{*}$} \\
\hline & $\begin{array}{c}\mathrm{T}_{1} \\
\text { (Control) }\end{array}$ & $\mathrm{T}_{2}$ & $\mathrm{~T}_{3}$ & $\mathrm{~T}_{4}$ & $\mathrm{~T}_{5}$ & \\
\hline Initial weight, g/fish & 10.11 & 10.13 & 10.11 & 10.12 & 10.10 & 0.07 \\
\hline Final weight, g/fish & $36.75 b$ & $37.00 \mathrm{~b}$ & $41.97 \mathrm{a}$ & $42.92 \mathrm{a}$ & $42.64 \mathrm{a}$ & 0.54 \\
\hline $\begin{array}{l}\text { Average total gain1, } \\
\text { g/fish }\end{array}$ & $26.64 \mathrm{~b}$ & $26.87 \mathrm{~b}$ & $31.86 \mathrm{a}$ & $32.80 \mathrm{a}$ & $32.54 \mathrm{a}$ & 1.52 \\
\hline $\begin{array}{l}\text { Average daily gain }{ }^{2}, \\
\text { g/fish/day }\end{array}$ & $0.32 \mathrm{~b}$ & $0.32 \mathrm{~b}$ & $0.38 \mathrm{a}$ & $0.39 \mathrm{a}$ & $0.39 a$ & 0.07 \\
\hline $\begin{array}{l}\text { Specific growth rate3 } \\
\text { (SGR \% /day) }\end{array}$ & $1.53 \mathrm{~b}$ & $1.54 \mathrm{~b}$ & $1.69 \mathrm{a}$ & $1.72 \mathrm{a}$ & $1.71 \mathrm{a}$ & 0.11 \\
\hline Survival rate $4, \%$ & 90 & 90 & 95 & 100 & 100 & 2.10 \\
\hline $\begin{array}{l}\text { Feed intake (FI), DM } \\
\mathrm{g} / \text { fish }\end{array}$ & $47.36 \mathrm{a}$ & $45.96 \mathrm{ab}$ & $44.60 \mathrm{~b}$ & $42.98 \mathrm{c}$ & $42.63 \mathrm{c}$ & 1.86 \\
\hline $\begin{array}{l}\text { Feed conversion ratio5 } \\
\text { (FCR) }\end{array}$ & $1.78 \mathrm{a}$ & $1.71 \mathrm{~b}$ & $1.40 \mathrm{c}$ & $1.31 \mathrm{~d}$ & $1.31 \mathrm{~d}$ & 0.11 \\
\hline $\begin{array}{l}\text { Protein efficiency ratio6 } \\
\text { (PER) }\end{array}$ & $1.87 \mathrm{c}$ & $1.94 \mathrm{c}$ & $2.37 \mathrm{~b}$ & $2.53 \mathrm{a}$ & $2.53 \mathrm{a}$ & 0.20 \\
\hline $\begin{array}{l}\text { Protein productive value } \\
7 \text { (PPV, \%) }\end{array}$ & $30.29 c$ & $36.64 \mathrm{~b}$ & $45.44 \mathrm{a}$ & $48.70 \mathrm{a}$ & $49.12 \mathrm{a}$ & 1.21 \\
\hline $\begin{array}{l}\text { Energy retention8 } \\
(\mathrm{ER}, \%)\end{array}$ & $21.71 b$ & $23.43 \mathrm{~b}$ & $28.65 \mathrm{a}$ & $30.50 \mathrm{a}$ & $30.66 \mathrm{a}$ & 1.07 \\
\hline
\end{tabular}

*Means in the same rows having different superscript letters were significantly different at $P<0.05$ levels.

*Standard error of the mean derived from the analysis of variance.

Table 3: Growth performance parameters of Nile tilapia (O. niloticus) fed on the experimental diets.

\begin{tabular}{|l|l|c|c|c|c|c|c|}
\hline & $\begin{array}{l}\text { Initial } \\
\text { Items }\end{array}$ & \multicolumn{5}{|c|}{ Treatments } & SE* $^{*}$ \\
\hline & & $\mathbf{T}_{1}$, Control & $\mathbf{T}_{2}$ & $\mathbf{T}_{3}$ & $\mathbf{T}_{4}$ & $\mathbf{T}_{5}$ & \\
\hline Wet weight, \% & 78.48 & 73.56 & 72.89 & 72.79 & 72.75 & 72.73 & 2.24 \\
\hline Crude protein, \% & 53.15 & 56.41 & 56.51 & 57.68 & 57.86 & 58.24 & 1.33 \\
\hline Ether extract, \% & 16.95 & 19.87 & 19.75 & 19.66 & 19.57 & 19.70 & 0.50 \\
\hline Ash, \% & 13.25 & 15.97 & 15.86 & 15.68 & 15.60 & 15.54 & 0.11 \\
\hline Energy, Kcal/100 g & 531 & 539 & 539 & 543 & 541 & 543 & 2.87 \\
\hline
\end{tabular}

*Means in the same columns having different superscript letters were significantly different at 0.05 levels.

*Means of the standard error derived from the analysis of variance.

Table 4: Effect of Digeston-1 on Nile tilapia body composition (\%, on wet weight basis not).

Total proteins (TP) was measured according to the method of Henry [19] using reagent kits obtained from Diamond Diagnostic Company, Egypt. Alanine Aminotransferase (ALT; U|L) and Aspartate Aminotransferase (AST; U|L): and activities were assayed according to the method of Reitman and Frankel [20] using reagent kits purchased from Randox Company, UK.

\section{Statistical analysis}

Data were statistically analyzed using SPSS software program [21] for one-way analysis of variance. When F-test was significant, least significant difference was calculated according to Duncan [22].

\section{Results and Discussion}

\section{Survival rate growth responses to digeston-1}

The survival rate of Tilapia fingerlings ranged between 90 and 100\% and was significantly $(P<0.05)$ affected by dietary addition (Table 3$)$ Fingerlings fed supplemented diets containing Digeston-1 had higher gain, ADG, and SGR compared to unsupplemented one specifically at 0.5\% Digeston-1 supplementation. Fish fed control diet (D1) exhibited the lowest final body weight ( $32.75 \mathrm{~g} /$ fish) while D4 group exhibited the highest weight (42.92 g/fish).

Feed intakes were significantly decreased $(\mathrm{P}<0.05)$ in fish fed the Digeston-1 (FSBM) diets compared with fish in the control group by 3 , 6,9 and $10 \%$ for $\mathrm{T}_{2}, \mathrm{~T}_{3}, \mathrm{~T}_{4}$ and $\mathrm{T}_{5}$, respectively.

Feeding supplemental diets with Digeston-1 to fish groups (D4 and D5) had significant decreased values $(P<0.05)$ of feed conversion ratio compared with the control group. The best conversion ratio was achieved by 0.50 and $0.70 \%$ Digeston- 1 additions (1.31 and 1.31 feed intake/live weight gain) compared with control group (1.78 feed intake/live weight gain). Generally, the best feeding efficiency was detected by fish fed supplemental diets with Digeston-1 than those fed the control diet. Digestaon-1 supplementation increased the protein efficiency ratio (PER), protein productive value (PPV \%) and energy retention $(\mathrm{ER} \%)$ significantly $(P<0.05)$ especially, with $0.30,0.50$ and $0.70 \%$ supplementations. The lowest values of PER, PPV and ER were recorded for the control fish.

Growth performance parameters estimated in present study indicated that, Digeston-1 has a positive effect on growth rates and feed utilization of Nile tilapia fingerlings especially; fish fed diets containing $0.50-0.70 \%$ Digeston-1 (Table 3). The addition of Digeston-1 to the diets increased the body weight $(16 \%)$ with the superiority of a high level of Digeston-1 (0.5 and $0.7 \%$ on diet). The improved growth of tilapia fingerlings fed on the diet supplemented with high Digeston-1 level may be due to modified fermentation, increased feed utilization and reduce excretion of endogenous nitrogen [23]. 
Body chemical composition ( DM, CP, EE, Ash and energy content) of Nile tilapia at the beginning and the end of the experiment is shown in Table 4. There was no change in whole body composition among all experimental diets. Results showed that no significant differences $(P>0.05)$ were observed in moisture, crude protein, ether extract, ash and energy content of Nile tilapia fed diets containing various levels of Digeston-1.

Growth performance and survival rate of Nile tilapia were improved with the inclusion of Digeston-1 in fish diets. Similar findings were reported by El-Hais et al. [24] using digestamin which contained FSBM as one of its components. They found that the addition of digestamin in the diets, especially at levels 0.15 and $0.20 \%$ improves and enhances the growth performance of Nile tilapia fingerlings. Yamaoto et al. [25] showed that the fermentation by compound bacteria predominantly Bacillus spp. for $10 \mathrm{~h}$ until material temperature reached $80^{\circ} \mathrm{C}$ improved the nutritive value of soybean meal, and the non-fish meal diet containing this fermented soybean meal at $47.6 \%$ level attained similar growth performance, nutrient digestibility and physiological conditions such as biliary bile status and intestinal and liver morphologies in rainbow trout to fish fed the fish meal-based diet.

Fermentation of SBM can provide partially digested soy proteins that are utilized better, have trypsin inhibitors (one of the major antinutritional compounds) removed and have modified AA profiles resulting from microbial AA synthesis and breakdown [3]. Trypsin inhibitor concentration in SBM can be reduced after fermentation as well and the reduction in trypsin inhibitor concentration can improve protein digestion in the small intestine. Therefore, the improved growth may be attributed mostly to the improvement in the nutritional value and the elimination of antinutritional factors in fermented soybeans [3]. Fan et al. [26] found that markedly lower concentrations of antinutritional components such as phytic acid, lectin, and urease were found in FSBM as compared with nonfermented SBM. Similarly, $\mathrm{Wu}$ and Jing [7] suggested that fermentation could improve protein

\begin{tabular}{|c|c|c|c|c|c|c|}
\hline \multirow[t]{2}{*}{ Items } & \multicolumn{5}{|c|}{ Treatments } & \multirow[t]{2}{*}{ SE* $^{*}$} \\
\hline & Control & $\mathbf{T}_{2}$ & $\mathbf{T}_{3}$ & $\mathrm{~T}_{4}$ & $\mathbf{T}_{5}$ & \\
\hline \multicolumn{7}{|l|}{ Blood picture } \\
\hline T. W. BCs $\left(10^{3} / \mathrm{mm}^{3}\right)$ & 20.75 & 21.35 & 21.75 & 22.25 & 22.35 & 2.31 \\
\hline T. R. BCs $\left(10^{6} / \mathrm{mm}^{3}\right)$ & 3.54 & 3.60 & 3.70 & 3.75 & 3.88 & 0.05 \\
\hline $\mathrm{Hb}(\mathrm{g} / \mathrm{dl})$ & 6.50 & 7.22 & 7.55 & 7.70 & 7.75 & 0.42 \\
\hline PCV (\%) & 22.75 & 23.97 & 24.25 & 25.25 & 25.50 & 2.10 \\
\hline \multicolumn{7}{|c|}{ Differential leucocytes count (\%) } \\
\hline Lymphocyte & $58.25^{\mathrm{b}}$ & $58.75^{\mathrm{b}}$ & $60.50^{\mathrm{ab}}$ & $61.58^{\mathrm{ab}}$ & $63.25^{\mathrm{a}}$ & 1.89 \\
\hline Monocyte & 1.25 & 150 & 1.75 & 2.00 & 2.00 & 0.01 \\
\hline Basophil & 0.75 & 0.75 & 1.00 & 0.75 & 1.00 & 1.21 \\
\hline Eosinophil & 1.50 & 1.75 & 2.25 & 2.25 & 2.50 & 1.86 \\
\hline Neutrophil & 25.50 & 25.75 & 26.50 & 26.50 & 26.75 & 2.34 \\
\hline \multicolumn{7}{|c|}{ Biochemical parameters } \\
\hline \multicolumn{7}{|l|}{ Protein } \\
\hline Total Protein (g/dl) & 2.60 & 2.75 & 2.80 & 2.85 & 2.95 & 0.20 \\
\hline Albumin (g/dl) & 1.20 & 1.23 & 1.26 & 1.27 & 1.28 & 0.11 \\
\hline Globulin(g/dl) & 1.40 & 1.52 & 1.54 & 1.58 & 1.67 & 0.11 \\
\hline \multicolumn{7}{|l|}{ Liver function } \\
\hline AST (U/L) & 63.25 & 61.50 & 62.75 & 63.30 & 62.14 & 2.10 \\
\hline ALT (U/L) & 20.25 & 19.00 & 20.25 & 19.75 & 20.00 & 0.16 \\
\hline
\end{tabular}

*Means in the same columns having different superscript letters were significantly different at 0.05 levels.

*Means of the standard error derived from the analysis of variance.

Table 5: Hematological and biochemical parameters of Nile tilapia fed on the experimental diets containing different levels of Digeston-1. digestibility, essential amino acid index (EAAI) and protein efficiency ratio (PER) of soybean meal (SBM). However, average total weight, feed efficiency and survival rate of shrimp fed $100 \%$ fish meal diet and $25 \%$ fermented soybean meal replacement had similar results.

Different effects can be expected from the lactic acid bacteria strains contained in the probiotic DIGESTON-1. The bacteria should have the ability to manifest themselves on the mucous of intestinal wall and thereby create a natural biofilm. The barrier of the intestinal wall is strengthened and so the access of disease causing germs to the resorptive epithelium is prevented. Such loss of lactic acid bacteria in the digestive system may be due to stress, change of feed, diseases or antibiotic treatment. Further on an improvement of the mucosal immunity can be reached.

\section{Hematological and biochemical blood parameters}

There were no significant $(P>0.05)$ differences among the tested dietary treatments (Table 5 ). The treated diets had slightly higher than control diet in white blood cells count (WBCs), red blood cells count (RBCs), hemoglobin $(\mathrm{Hb})$ and PCV. The numbers of leukocytes (WBCs) in fish blood are extremely variable even among conspecific individuals, even in similar conditions and depend on many factors. In the present study, the number of Leukocytes is a higher and it was at range $\left(20.75-22.35 \times 10^{3} / \mathrm{mm}^{3}\right)$ for all groups were within the range described by Osuigwe et al. [27]. Erythrocytes (RBCs) count at range $\left(3.54-3.88 \times 10^{6} / \mathrm{mm}^{3}\right)$ in the studied $O$. niloticus for all groups were within the range described by Homytowska et al. [28]. Similar observation was noted with other species such as Rhamdia quelen, Leucaspius delineates and Clarias gariepinus as reported by Borges et al. [29], and Sunbleak, Leucaspius delineates by Homytowska et al. [28] and Clarias gariepinus by Sotolu and Faturoti [30], respectively. The hemoglobin concentration $(6.50-7.75 \mathrm{~g} / \mathrm{dl})$ for all groups in studied fish was similar to those reported by Gbore et al., Ispir et al. and Ada et al. [31-33] but was lower than those of Curimbata $(9.7 \mathrm{~g} / \mathrm{dl})$ as reported by Adam and Agab [34]. Haemoglobin concentration was slightly increased with increasing dietary Digeston-1. In the present study, the mean values of packed cell volume (PCV) in O. niloticus were within the range of the corresponding values by Sotolu and Faturoti and Ada et al. [30,33].

There were significant $(P<0.05)$ differences in lymphocytes between treatment $\mathrm{T} 5$ and control treatment $(\mathrm{T} 1)$ but there were no significant $(P>0.05)$ differences between T1 to T4. There were no significant $(P>0.05)$ differences among the tested dietary treatments in (Mono, Baso, Eoso and Neutro).

The haematological picture showed an increase in the total erythrocytic and leucocytic cell count with marked increase in the percentage of lymphocyte and monocyte. From the histopathological view, these results indicate that Digeston-1 enhances the humoral immune response through increasing the number of activated B-lymphocyte and plasma cells in the spleen and bursa of the treated fingerlings.

On contrast, total protein was increased $(P>0.05)$ by Digeston- 1 supplementation specifically, by 0.50 and $0.70 \%$ level. These results suggested that, fish health was improved when fed Digeston-1 supplemented diets. Moreover, Digeston-1 supplementation had no significant effect $(P>0.05)$ on aspartate aminotransferase (AST) and alanine aminotransferase (ALT) concentrations compared with unsupplemented group. Biochemical analyses such as blood chemistry analyses often provide vital information aiding the diagnosis for health assessment and management of cultured fish [35-37]. 
Citation: Khalafalla MM (2013) Nutritive Value of Diets Containing Digeston-1 as a Feed Additive for Nile Tilapia (Oreochromis niloticus) Fingerlings. J Aquac Res Development 4: 192 doi:10.4172/2155-9546.1000192

Page 5 of 5

These results confirm previous findings by Abdel-Tawwab et al. [3840] that biochemical parameters were improved in fish fed probiotic during their study on the use of commercial probiotic as a growth and immunity promoter for Nile tilapia.

\section{Conclusion}

The results of the present study confirmed that the inclusion of Digeston-1 in the feed during Nile tilapia (Oreochromis niloticus) fingerlings rearing is positive for their growth. This was clearly indicated by an increase in weight gain by $16 \%$. The Nile tilapia in the trial groups consumed less feed which led to a considerable reduction of the feed costs. The inclusion rate of Digeston- 1 at $0.5 \%$ proved to be sufficiently efficient.

\section{References}

1. Li DF, Nelssen JL, Reddy PG, Blecha F, Hancock JD, et al. (1990) Transient hypersensitivity to soybean meal in the early-weaned pig. J Anim Sci 68: 17901799

2. Jiang R, Chang X, Stoll B, Ellis KJ, Shypailo RJ, et al. (2000) Dietary plasma protein is used more efficiently than extruded soy protein for lean tissue growth in early-weaned pigs. J Nutr 130: 2016-2019.

3. Hong KJ, Lee CH, Kim SW (2004) Aspergillus oryzae GB-107 fermentation improves nutritional quality of food soybeans and feed soybean meals. J Med Food 7: 430-435.

4. Kim SH, Yang JL, Song YS (1999) Physiological Functions of Chongkukjang Food Ind Nut 4: 40-46.

5. Windschitl PM (1992) Effects of probiotic supplementation of hull-less barleyand corn-based diets on bacterial fermentation in continuous culture of ruminal contents. Can J Anim Sci 72: 265-272.

6. Bohm J, Srour A (1995) An Austrian probiotic feed additive for Egyptian buffalo and cattle production. 3rdScientific Conference, Faculty of Veterinary Medicine, Assiut University (Egypt Society for Cattle Diseases), Dec. 3-5, Assiut, Egypt.

7. Wu D, Jing HH (1998) A study on the fermentation technology for soybean meal as feedstuff. Food Feed Ind 3: 18-20.

8. Skrede G, Storebakken T, Skrede A, Sahlstrøm S, Sørensen M, et al. (2002) Lactic acid fermentation of wheat and barley whole meal flours improves digestibility of nutrients and energy in Atlantic salmon (Salmo salar L.) diets. Aquaculture 210: 305-321.

9. Skrede G, Herstad O, Sahlstrøm S, Holck A, Slinde E, et al. (2003) Effects of lactic acid fermentation on wheat and barley carbohydrate composition and production performance in the chicken. Anim Feed Sci Tech 105: 135-148.

10. Shimeino S, Masumoto T, Hujita T, Mima T, Ueno S (1993) Alternative ProteinSources for Fish-Meal Diets of Young Yellowtail. Nippon Suisan Gakkaishi 59: $137-143$

11. AOAC (2000) Association of Official Analytical Chemists. Official Methods of Analysis. 16th Edn., AOAC, Arlington, Virginia, USA.

12. NRC (1993) Nutrient requirements of fish. National Academy Press, Washington D.C.

13. APHA, American Public Health Association (1999) Standard Methods for the Examination of Water and Wastewater. New York, USA. Pp. 769.

14. Boyd CE (1990) water quality in ponds for aquaculture. Auburn University, Auburn, AL. Brace Jovanovich. Toronto, Canada.

15. Stoskopf MK (1993) Fish Medicine. W.B. Saunders Company. Harcourt.

16. Zinkl JG (1986) Avian hematology. In: Schalm's Veterinary Hematology, Jain NC (Eds.). Philadelphia, Pai hea and Febiger.

17. Dacie SIV, Lewis SM (2006) Practical Haematology. 10th Edn. Churchill Livingstone, London. ISBN: 13:978-0-443-06660-3, pp: 736

18. van Kampen E, Zijlstra WG (1961) Standardization of hemoglobinometry. II. The hemiglobincyanide method. Clin Chim Acta 6: 538-544.

19. Henry RJ (1964) Colorimetric determination of total protein. In: Clinical Chemistry. Harper and Row Publ., New York, USA.

20. Reitman S, Frankel S (1957) A colorimetric method for the determination of serum glutamic oxalacetic and glutamic pyruvic transaminases. Am J Clin Pathol 28: 56-63.

21. SPSS (1997) Statistical package for the social sciences, Versions 6 , SPSS in Ch, Chi-USA.

22. Duncan DB (1955) Multiple Range and Multiple F-Tests. Biometrics 11: 1-42.

23. Yun JH, Kwon IK, Lohakare JD, Choi JY, Yong JS, et al. (2005) Comparative Efficacy of Plant and Animal Protein Sources on the Growth Performance, Nutrient Digestibility, Morphology and Caecal Microbiology of the Early-weaned Pigs. Asian-Aust J Anim Sci 18: 1285-1293.

24. El-Hais AMA, Khalafalla MME, Shymaa MMS (2011) Effect of different levels of digestamin supplementation on performance of Nile tilapia (Oreochromis niloticus) fingerlings. Egyptian J Nutrition and Feeds 14: 319-326.

25. Yamamoto T, Iwashita $Y$, Matsunari H, Sugita $T$, Furuita $H$, et al. (2010) Influence of fermentation conditions for soybean meal in a non-fish meal diet on the growth performance and physiological condition of rainbow trout Oncorhynchus mykiss. Aquaculture 309: 173-180.

26. Zhou F, Song W, Shao Q, Peng X, Xiao J, et al. (2011) Partial Replacement of Fish Meal by Fermented Soybean Meal in Diets for Black Sea Bream, Acanthopagrus schlegelii, Juveniles. J World Aquacult Soc 42: 184-197.

27. Osuigwe DI, Nwosu C, Ogunji JO (2007) Preliminary Observations on some Haematological Parameters of Juvenile Heterobranchus Longifilis Fed Different Dietary Levels of Raw and Boiled Jackbean (Canavalia ensiformis) Seed Meal. Conference on International Agricultural Research for Development. University of Kassel-Witzenhausen and University of Göttingen, October, pp: 9-11.

28. Homatowska A, Wojtaszek J, Adamowicz A (2002) Haematological Indices and Circulating Blood Picture in the Sunbleak, Leucaspius delineatus (Heckel, 1843). Zologica Poloniae 47: 57-68

29. Borges A, Scotti LV, Siqueira DR, Jurinitz DF, Wassermann GF (2004) Hematologic and serum biochemical values for jundiá (Rhamdia quelen). Fish Physiol Biochem 30: 21-25.

30. Sotolu AO, Faturoti EO (2011) Growth performance and hematological effects of varying dietary processed leucaena leucocephala seed meal in clarias gariepinus (burchell, 1822) juveniles. African Journal of Food, Agriculture, Nutrition and Development 11: 4547-4557.

31. Gbore FA, Oginni O, Adewole AM, Aladetan JO (2006) The Effect of Transportation and Handling Stress on Haematology and Plasma Biochemistry in Fingerlings of Clarias gariepinus and Tilapia zillii. World $\mathrm{J}$ Agriculture Sciences 2: 208-212

32. Ispir U, Yonar ME, Oz OB (2011) Effect of Dietary Vitamin E Supplementation on the Blood Parameters of Nile Tilapia (O. niloticus). The Journal of Animal and Plant Sciences 21: 566-569.

33. Ndome FBA, Chris B, Bayim B, Peter-Robins (2011) Some Haematological Changes in O. niloticus Juveniles Exposed to Butachlor. Journal of Agriculture and Food Technology 1: 73-80.

34. Adam HM, Agab H (2008) Haematological and biochemical indices of Clarias garipeinus collected from River Nile, Sudan. Sudan Academy of Sciences J 2 : 67-72.

35. Cnaani A, Tinman S, Avidar Y, Ron Mm, Hulata G (2004) Comparative study of biochemical parameters in response to stress in Oreochromis aureus, $\mathrm{O}$. mossambicus and two strains of O. niloticus. Aquac Res 35: 1434-1440.

36. Řehulka J, Minařík B, Řehulková E (2004) Red blood cell indices of rainbow trout Oncorhynchus mykiss (Walbaum) in aquaculture. Aquac Res 35: 529-546.

37. Abdel-Tawwab M, Mousa MAA, Abbass FE (2007) Growth performance and physiological response of African catfish, (Clarias gariepinus) fed organic selenium prior to the exposure to environmental copper toxicity. Aquaculture 272: $335-345$

38. Abdel-Tawwaba M, Abdel-Rahman AM, Ismaela NEM (2008) Evaluation of commercial live bakers' yeast, Saccharomyces cerevisiae as a growth and immunity promoter for Fry Nile tilapia, Oreochromis niloticus (L.) challenged in situ with Aeromonas hydrophila. Aquaculture 280: 185-189.

39. Hepher B, Liao IC, Cheng SH, Haseih CS (1983) Food utilization by red tilapia-Effects of diet composition, feeding level and temperature on utilization efficiencies for maintenance and growth. Aquaculture 32: 255-275.

40. Jauncey K, Ross B (1982) A Guide to Tilapia Feeds and Feedings. Institute of Aquaculture, University of Stirling, FK94 La, Scotland, U.K. 